\title{
The Invention of a Medical Institution? A Discussion of Hospitals Around 1800
}

\author{
Fritz Dross
}

$\mathrm{D}$ iscussing health care between self-help, intermediary organisations and formal poor relief in terms of choices between the informal and the formal it seems quite clear on which side research of hospitals in the late $18^{\text {th }}$ century is placed. Based on the formula of the "Birth of the Clinic" and relying on sociological research of hospitals of the late 1960s and 1970s wide parts of the German-speaking social history of medicine dedicated to the $19^{\text {th }}$ and early $20^{\text {th }}$ century development of the modern hospital claimed their historical subject to be "one of the most complex institutions of man." This research abandoned the suggestion of a long-term transition from the medieval hospital to the late $20^{\text {th }}$ century high-techclinic in which religion has been slowly disappearing from hospitals while clinical observation and permanently growing knowledge of nature of disease and finally scientific medicine captured the charitable home of benevolence. ${ }^{2}$ This research had to suggest a systematic rupture around $1800 .{ }^{3}$ Two reasons were named for that. Firstly, in a systematic sense, the main objective of medieval and early modern hospitals was not the physical cure of sick patients (i.e. the restoration of their ability to work). Being a charitable foundation it was dedicated to the salvation of its founder's soul. Secondly, as a historical argument, it is obviously striking that the modern hospital fits extremely well in the discourse of medical police in the late $18^{\text {th }}$ century. ${ }^{4}$ An example reference for these discussions is the German book published in 1790: "On the advantages of (modern) hospitals for the state."

Both arguments have been criticised in recent historical research. On the one hand, one could ask if there were any institutions that were not dedicated to the salvation of the Christians' souls in medieval Europe. At least in this very shortened form, the systematic argument is not really convincing. Furthermore, there was of

1 Labisch/Spree, 1996; Labisch / Spree, 2001; Stollberg/Tamm, 2001; Rohde, 1974. The citation of Edward D. Churchill is from Faxon, 1949, p. 1.

2 Jetter, 1969, p. 121-138; Jetter, 1977; Murken, 1988.

3 Labisch: Stadt, 1996, p. 287.

4 Dinges, 2000; Wahrig / Sohn, 2003.

5 "Von den Vortheilen der Krankenhäuser für den Staat". Markus, 1790. 
course curing in early modern hospitals, at least since the $16^{\text {th }}$ century. ${ }^{6}$ To give a prominent example, one could name the hospitals dedicated to the so called "French disease" (Syphilis) which were houses where academically trained medical doctors treated their patients in order to cure them within several weeks. On the other hand, late $18^{\text {th }}$ century discourse had not only popular proponents of modern hospital care but also strong arguments for domiciliary care.

In the following I will try to develop some arguments for a hypothesis which I would like to call "the invention of a medical institution". Like Micheline LouisCourvoisier, who asked the very convincing question: "Why attend a hospital if one is ill in the late $18^{\text {th }}$ century", I want to ask "Why does a society discuss hospital care, while there is obviously no medicine, which could cure better there than in the homes of the sick"? While the epistemological change of medicine led to the "Birth of the Clinic" (Michel Foucault), I want to take a look at historical circumstances, which generated demand for and acceptance of new forms of public welfare. Deciding whether to go to a hospital or not is obviously dependent on the offer to have a hospital to go to.

Social institutions are not invented in enlightened moments of a sole genius. The formula of an "invention of an institution" is understood as a result of a debate which reflects and which at the same time is strongly depending on its own social conditions and necessities in its culturally and historically given language. Maybe there will be a chance to understand the hospital as "one of the most complex institutions of man" if we take a look at a very early stage of discussion, when there still were several options to achieve the institutional aim. In a historical perspective one has to draw special attention to failed hospital foundation and to choose a starting point, when the contemporary debate still knew serious arguments against hospital cure.

I am not going to present a concise theory of institutions or institutionalisation in history for several reasons. In a wider, sociological sense, the term institution means an organised group of interacting individuals in order to satisfy basic and persistent needs with common values and shared norms, which define interaction in the group as well as the communication of the institution with outside individuals, other institutions and the outside world. 'Sociologists use the term to describe phenomena like economy and consumption or family and kinship, for example. If in this case, for example, family is one of the oldest and strongest institutions maybe of mankind in general, it will hardly be possible to draw a line between self-

6 Knefelkamp, 1989; Stein, 2003; Jütte, 1996, p. $34 f$.

7 Dross, 2004, p. 84-112.

8 "Pourquoi aller à l'Hôpital quand on est malade au XVIIIième siècle?" LouisCourvoisier, 2000.

9 Rohde, 1974, p. 91-125; Robertson, 1987, p. 93; Lenski / Nolan, 1991, p. 43; Macionis/Plummer, 1997, p. 407-604; Eder 1997. 
help and institutional help, which should be one of the major aims of this volume. At the same time theories about institutional externalisation and organisational professionalisation of institutions are already well-known. To give some more historical pieces of circumstantial evidence does not contribute all-too-much to our purpose. In this sense, my method is theoretically low-leveled as I suppose that there was something like a hospital, which could be the subject of a debate. Given merely linguistic and situational evidence in this first step, I want to understand what the debate about hospitals historically was about and thus have to avoid assuming exclusive criteria of what hospitals should have been in a frameset of a strong theory of modernisation. This way I hope to get a trace for historically understanding a process of institutional and, in the end, social change.

The analysis is divided into two major parts. Firstly I am going to present some examples of the non-foundation of hospitals. Based on archival material and cases given in the literature, I intend to reflect on the administrative problems coming along with the foundation of hospitals in late absolutist and early $19^{\text {th }}$ century Germany. As hospitals tend to be expensive organisations one will firstly be confronted with the overall lack of funds. Furthermore, the frictional resistance of the historical administrative organisational frame can be observed. Both are not specifically connected with deliberating the foundation of a hospital, of course.

Obviously the main promoters of hospital foundations have been doctors, sometimes invisible behind their princes, who formally gave the instructions to begin the deliberations among the governmental bodies. Thus, doctors should have been prepared with conclusive arguments in favour of hospitals. This would be the point where medical expertise should have been translated into political and administrative discourse.

Beyond that transition in argumentation from medical into political debate, one has to look at the discussion between the doctors themselves to completely comprehend the transition. The second part of this paper aims to introduce that discussion. Late absolutist Germany has been depicted as the era of "medical police" accompanied by a wave of hospital foundations throughout the bigger and the smaller territories. ${ }^{10}$

The position claiming "the advantages of hospitals for the state" is very much better known ${ }^{11}$ whilst the contra-position is so underestimated that a real discussion is scarcely visible so far. Based on an analysis of late $18^{\text {th }}$ and early $19^{\text {th }}$ century (mostly medical) periodicals, a brief overview of the debate concerning hospitals will be given. The two main positions in the debate on hospitals around 1800 (i.e. pro and contra hospital care) will be regarded with respect to their ability to create convincing arguments on the background of historical discourse. This reasoning

10 See the list in Murken, 1988, p. 268; Paul, 1996.

11 Paul, 1996. 
allows for a close look at the contemporary thinking of what hospitals are, of what healing is, and, of course, of what medicine is about. Finally, in conclusion I want to reconsider the position of the late $18^{\text {th }} /$ early $19^{\text {th }}$ century hospital and its historically given alternatives in terms of institutional care and the formal versus the informal in health care and poor relief.

Below, two efforts to establish a hospital will be considered for emphasising the arguments suggesting their foundation or non-foundation respectively. These cases have been analysed in a case study on the German town Düsseldorf (approximately 20,000 inhabitants around the year 1800), which was the capital of the territory of Jülich-Berg in north-western Germany. ${ }^{12}$

Johann Peter Brinckmann, the director of the Medical Authority of Jülich-Berg was the first to suggest the foundation of a modern hospital in Düsseldorf in 1776. Once he found 14 people in one house who had fallen ill with "rotten fever" ${ }^{13} \mathrm{He}$ proposed a hospital which could break the vicious circle of poverty caused by the inability to work and the hardly avoidable infection of the other members of the household, the house and - at the worst - the whole quarter. As a member of government, Brinckmann reported his suggestion to the prince, the elector of the palatinate Karl Theodor, who instructed his privy council to deliberate the matter. They conferred quite elaborately, but 20 years later there was still no hospital founded. ${ }^{14}$

Noteworthy is the fact that Brinckmann did not only address his prince but also the well-known statesman and historian Justus Möser in Osnabrück. The debate on hospitals was obviously not exclusively a debate among physicians and doctors. Möser knew that hospitals were expensive and that proposing their foundation needed good arguments. According to Möser these were: the cure of the poor sick and the education of physicians as well as the scientific development of medicine itself. Since Düsseldorf was not big and had no University, Möser dissuaded Brinckmann from the foundation of a hospital in this town. Despite this advice Brinckmann continued his initiative to establish a hospital in Düsseldorf.

The second attempt to found a "modern" hospital in Düsseldorf in the year 1786 did not rely on the governmental authorities. ${ }^{15}$ Johann Andreas Varnhagen propagated his concern to the public via press. Within a few weeks he gained almost 30 members for his philanthropic society which was to support a hospital for the sick poor. Being a physician, as his predecessor, Varnhagen focused on those who earned their living in good times without earning enough to save some money or just food to have enough in times of rising prices or unemployment. Even the least dangerous diseases had a lot of victims among the undernourished poor living in

12 Dross, 2004.

13 "Faulfieber" or "faules Fieber". Brinckmann, 1997, p. 19-21.

14 Dross, 2004, p. 174-182.

15 Ibid, p. 182-199. 
the most unclean and impure homes which Varnhagen knew but the government forbade his advertisements and in 1791 he left Düsseldorf for Strasbourg as he was an adherent of the early revolutionary movement in France.

In 1792, the governmental commission which was still deliberating the older proposal of Johann Peter Brinckmann conceived a hospital comprising three parts: one for the old and weakened, another for people with infectious diseases and a third one for servants in order to protect the homes of their masters. But there was still no hospital founded. Thus, there was no hospital in Düsseldorf in the 1790s. At the same time, the idea of a hospital for the sick poor was already well-known among the governmental personnel and the newspaper-reading intelligence and merchants.

In the Westphalian city of Münster, the first attempt to found a new hospital in the $18^{\text {th }}$ century goes back to the bishop Clemens August who established a mission of the Hospitaller Brothers of St. John of God in Münster in the early 1720s. But to build up a new hospital took several attempts before 1754, when the patients where moved to the new hospital building, which contained 16 beds only for men. ${ }^{16}$ One could expect that this should have changed after Christoph Ludwig Hoffmann in 1764 came to Münster. Hoffmann was one of the most famous protagonists of medical reform in terms of "medical police". He was in close contact with the above mentioned Justus Möser and Hoffmann's reorganisation of the Medical Authority of the bishopric Münster was copied in several other territories as well as it was the archetype of Brinckmanns' respective reform in Jülich-Berg. ${ }^{17}$

The governmental deliberations to found a new hospital in Münster started in 1784 - exactly the year of the completion of the famous General Hospital in Vienna containing about 2,000 beds. In the course of the governmental deliberations several examples of medical care were discussed. On the one hand the big hospital projects in Vienna and Würzburg had been under consideration. On the other hand, already in 1785 a goldsmith from Cologne reported his experiences concerning domiciliary care driven by beguines. Already in an early stage of debate, the planning of a big new hospital was abandoned in favour of a smaller one which, in addition to the St. Clemens hospital for men, should have been founded as a hospital only for women conducted by a female catholic order. ${ }^{18}$ In the end, no hospital was founded. In 1810 the St. Clemens hospital was incorporated into the municipal poor relief organisation and after the brothers had left in 1818, their former rooms were devoted to the medical care of women. ${ }^{19}$

In 1786/87 Hoffmann left Münster when he was called to conduct a principal reorganisation of the medical authority by his patient Friedrich Karl Joseph von

16 Jungnitz, 1981, p. 25-40.

17 Terhalle, 1987, p. 101-124; Brinckmann, 1997, p. 3; Labisch, 1997, p. 38-40.

18 Jungnitz, 1981, p. 70-73.

19 Ibid, p. 74. 
Erthal, the elector and archbishop of Mainz. In Mainz again he was engaged with the question of hospital care. The new academic hospital had just opened when Hoffmann in 1788 published a small brochure claiming the necessity to provide not only a bed but a single room for each patient and thus affronting his colleague and medical professor in Mainz, Carl Strack, who conducted the project of the new academic hospital in Mainz. ${ }^{20}$

Obviously, there were two strong complexes of argumentation. On the one hand the clinical complex comprising the suggestion that (academic) hospitals would provide a better education of physicians which could be linked to the Leyden school of academic medical teaching. ${ }^{21}$ Furthermore, the suggestion that medical knowledge as a whole could be improved by systematic awareness of medical observation which could be linked to the empiricist movement of late $18^{\text {th }}$ century science in general. On the other hand we have the complex of argumentation that curing the poor in hospitals would be quite useful - if not necessary - for the common best. ${ }^{22}$ The most successful hospital foundations like those in Vienna and Würzburg came along with both major revisions in the medical teaching system as well as in the organisation of poor relief. ${ }^{23}$ In Göttingen poor relief reform conducted by the magistrate and reforms in academic medical training driven by the University could not agree. In consequence, the "Birth of the Clinic" in Göttingen (as well as for example in Halle and Jena) preferred a policlinical model avoiding the foundation of a big and expensive hospital. ${ }^{24}$ Würzburg, Bamberg and of course Vienna seemed to have been the exceptions proving the rule.

At the same time, one can detect two main points of criticism. Obviously, the cost of a hospital foundation, especially of building a hospital, could be avoided if domiciliary care would have been strengthened. Thus, without convincing arguments referring to the better chances of healing the patients and educating medical students hospital projects could hardly be debated seriously. The question how to plan and realise a hospital with respect to the location of the building and the design of the rooms even between physicians in favour of hospital care was still not unanimously decided as for example the Mainz case shows.

The problems got even worse when, in the beginning of the $19^{\text {th }}$ century, doctors translated the argumentation of separating the curable and the incurable into the field of psychiatric ailments. Consequently, they had to persuade the state authorities to convert prisons and old-type hospitals into hospitals for the curable mentally ill. At the same time the prison itself changed its goal from just punishing criminals into their betterment. As well, early general hospitals usually rejected mentally ill

20 Hoffmann, 1788a; Strack, 1788; Hoffmann, 1788 b.

21 Bueltzingsloewen, 1997; Karenberg, 1997.

22 Cunningham / Grell / Jütte, 2002.

23 Brinkschulte, 1996; Karenberg, 1997.

24 Bueltzingsloewen 1997, p. 42f.; Karenberg, 1997, p. 33. 
people in order to prove their ability to heal their patients. Around 1800 justice and medicine developed the analog model of an organisation aiming to better the bourgeois society by isolating their clientele. But these were referring to three at least theoretically clearly separable groups as their clientele: criminals (penitentiary/prison), the mentally ill (lunatic asylum/psychiatric hospital) and the poor sick (general hospital). This is the "discovery" of Michel Foucault, of course. But as all of these institutions of betterment had been (and still are) quite expensive organisations, at the moment of their "invention" they had to compete for the devotedness of the state for their goals. ${ }^{25}$

This has been studied for the case of Pforzheim/Heidelberg/Illenau in southwestern Germany and Munich. ${ }^{26}$ Even more complicatedly undulated the debate on the foundation of a lunatic asylum in Hesse which began in 1806 and did not end before 1876 with an academic hospital in Marburg. ${ }^{27}$ The first project suggested a lunatic asylum on the outskirts of Kassel and was proposed by the municipal physician but opposed by the burgomaster who preferred the Kassel Charité to leave some rooms for the mentally ill. Whilst the (general) hospital in Kassel (and elsewhere in Germany) tried to get rid of the lunatics in favour of curing the physically sick, the early $19^{\text {th }}$ century discourse on hospitals for curable mentally ill people preferred locations in the countryside but rejected incurable and raving lunatics from hospital care. Since 1831, the medical authority as well as the parliament of Hesse discussed a clinical association of a lunatic asylum with the university of Marburg, which contradicted the concept of an idyllic location on the countryside as well as the idea that ease and order should be the main factors in curing the mentally ill.

A remarkable summary of the older debate on hospitals can be found in a memorandum which the state physician of the Düsseldorf Department Franz Joseph Servaes unsolicitedly sent to the ministry of the interior in 1810 ("Considerations of a sanitary police on charitable establishments and the related care for the poor and sick"). ${ }^{28}$ Having arrived in Düsseldorf just some months before, he obviously wanted to demonstrate his ambitions to the government. The first thing to learn from that is the point that Servaes obviously assumed the governmental personnel, if not the minister of the interior himself, were willing to read his essay on domiciliary versus hospital care because he suggested medical advice in matters of poor relief. The doctor addressed the government of a very new state, the Great Duchy of Berg, which was founded by Napoleon I. not before 1806. Beneath

25 Dross, 2006.

26 Chmielewski, 2003; Chmielewski, 2006; Lederer, 2003.

27 Vanja, 2001.

28 „Sanitäts Polizeyliche Betrachtung über die Wohlthätigkeits-Anstalten in Hinsicht der damit verbundenen Armen und Krankenverpflegung" Hauptstaatsarchiv Düsseldorf, Großherzogtum Berg 5513. Dross, 2004, p. 199-208. 
juridical reform, centred around the introduction of the Code Napoleon, and far reaching reforms in governmental administration the new state was indeed occupied with matters of a modern system of poor relief under unitary responsibility of the state but performed by local authorities. ${ }^{29}$

The Servaes' memoir comprises 45 paragraphs on 83 recto verso handwritten pages. In general, it cannot be taken as being especially witty in substance. However it shows that the discourse on medical police was well-known below the level of the all-time cited authorities in the early $19^{\text {th }}$ century. Servaes very clearly provides a concise summary of the standard topics treated in the discourse on medical police.

My attention to that manuscript was first attracted by the fact that his author stated a very concrete position pro-hospital care. Further in-depth reading revealed that Servaes in his memoir cited two famous authors, both physicians: August Friedrich Hecker and Christoph Wilhelm Hufeland. Of course, Servaes did not mention them. Those, let me say "mid-level" physicians like Servaes, did not only know the general topics of the discourse, but they had also read the original texts and they were able to compose new texts out of their precise knowledge. Servaes combined the original texts in a very special way: following the structure of Hufeland's essay, which was not published before 1809, he puts the arguments of Hecker taken from an essay published in 1793. The result can not be called trivial because both essays took the completely opposite view in the mentioned debate on domiciliary versus hospital care. That way, Servaes provided his government with a commented survey of the medical debate on hospitals.

The medical debate on hospitals and domiciliary care ("Besuchsanstalten") after the 1780s reflected on the role of medicine in fighting beggary and poverty by means of health care provision in poor relief and in providing the state with a healthy population in terms of "medical police". ${ }^{30}$ It began in Hamburg ${ }^{31}$ in 1785 after some physicians had been infected with the so-called "rotten fever" and gained wide publicity when in 1785 the historian and publicist Georg August Schlözer published the articles of Hamburgian physicians Philipp Gabriel Hensler and Daniel Nootnagel in his "Stats-Anzeigen". ${ }^{32}$ The German debate also looked for international discussion on the topic. In 1791 Johann Christian Friedrich Scherf published his translation of a French publication in his famous "Beyträge zum Archiv der medizinischen Polizei und der Volksarzneikunde". ${ }^{33}$

29 Dross, 2004, p. 247-252. The development in the "german" Départements - on the left bank of the Rhine - of the Napoleonic empire has been studied by Hudemann-Simon, 1995; Hudemann-Simon 1997.

30 Brinkschulte, 1996, p. 191f.; Bueltzingsloewen, 1997, p. 87-100.

31 Lindemann, 2002; Jütte, 1997.

32 Nootnagel, 1785; Hensler, 1785.

33 d'Apples Gaulis, 1786. 
In the first instance the Hamburg debate discussed the risk for physicians to be infected by their patients, stating "it would not be the same if a sanguine young doctor or a journeyman would die from the pox." ${ }^{34}$ But the question, whether the risk of infection was greater in the malodorous hovels of the poor or in a synthetical environment accommodating all kinds of diseases in a highly concentrated manner could not be answered by and with scientifically convincing arguments. Beneath the risk of infection Hensler and Nootnagel paid special attention to the character and role of the interaction between a doctor and his patients. Hensler claimed the hospital as the perfect environment for the observation of the course of disease, diet, medication, heating etcetera whilst Nootnagel worried about the doctor getting confused among all the ill people whose names he would hardly be able to remember. When visiting patients in their homes the young doctors especially could concentrate on one sick person taking notice even of hardly visible symptoms as well as the concrete circumstances of living. In reaction to the superior social position of the doctor, patients would feel honoured and behave much more mercifully and servilely if visited at their homes.

In 1793, August Friedrich Hecker published his essay on "Which are the most convenient and cheapest means of providing the poor sick with the required (medical) help?" 35 This essay can be regarded as the almost classical argumentation in favour of hospitals and was the base of Servaes memoir. His argumentation begins distinguishing different groups of poor. He specifically defines who should generally not be entitled to hospital care: idle beggars and vagrants are not to be helped by the public. This is the very consequence of the discourse on poverty elaborated since the $15^{\text {th }}$ century. Furthermore, hospitals do not have to incorporate patients with incurable diseases - this is one of the general parts of a definition of a modern hospital. The hospital is defined as an institution for curing people, who in better days are earning just enough to survive by their daily work or work by the day.

Following Hecker, there are at least four major advantages of hospitals compared to domiciliary care: 1) A doctor could medicate considerably more patients if they were in one place. 2) In the hospital, the nursing personnel are trained and monitored by doctors. In the homes of the poor the relatives do not care for their sick fathers, mothers, brothers and sisters as the bourgeois prejudice might assume. 3) In a hospital, besides diet, fresh and clean air, ventilation, illumination and heating are controlled by doctors in favour of the cure of the patients. Hecker suspects that a nursing family sold the food and the medication instead of giving it to the ill family member. 4) As a consequence of the better hospital environment, the risk of infec-

34 „Es ist doch nicht eins, ob ein unbeerbter Kurfürst, oder sein Trompeter, in den Pocken verhudelt wird. Und es ist auch nicht völlig einerley, ob ein hoffnungsvoller junger Arzt, oder ein Handwerks-Bursch, dahin stirbt." Hensler, 1785.

35 „Welches sind die bequemsten und wohlfeilsten Mittel, kranken Armen in den Städten die nöthige Hülfe zu verschaffen?"“ Hecker, 1793. 
tions in a hospital is very low. The question whether patients in hospital deprave of morality is in Hecker's view simply ridiculous and not to be taken into consideration.

The most striking in Hecker's essay is his enormous self-awareness in presenting quite unassertive arguments. On the background of the contemporary debate one has to bear in mind that "rot" or "infection" are metaphorical terms differing considerably in meaning from what is meant by "infection" in nowadays post-bacteriological medicine. There were neither "bacteria" nor "viruses" in late $18^{\text {th }} /$ early $19^{\text {th }}$ century discourse. ${ }^{36}$ In an essay on beggars in the countryside and in small towns, published in 1787 , this context becomes clearer:

The beggars have to be seen as numb and rotten members of society. One has to be aware that rot in a political as well as in a moral or a physical sense always proliferates, and by and by infects and depraves the healthy. ${ }^{37}$

Strictly opposed to Hecker's view was the one of Christoph Wilhelm Hufeland. The statement in his essay on the care for the sick poor in Berlin, published in 1809, summarises his position: Following Hufeland, the sick person "meets in hospitals the most lewd people, familiarised to idleness, and after staying in hospital for two or three months he will return from hospital with an ameliorated body but a deteriorated soul." ${ }^{38}$

Thus, hospitals do not suit the means of poor relief at all, which after all has an educational and a moral intention. Beyond that, neither medical education nor scientific observation or classification should take place in hospitals. Like Daniel Nootnagel in the Hamburg debate on hospitals in 1785, Hufeland also claimed the necessity for the doctor to be especially aware of the environment of his patients. In hospital, the doctor only sees what should be - only in the homes of the poor he can observe the real conditions. Therefore, Hufeland claims domiciliary care to be the perfect "clinical" institution:

In hospital young doctors are trained to be just artists. Solely in the homes of the poor, doctors learn to become men, sanctifying their art and the sense of philan-

36 Schott, 1998, p. 150-160.

37 „Diese [die Bettler, FD] sind nun ein für allemal schon als abgestorbene und in Fäulniß geratene Glieder der Gesellschaft anzusehen. Aber man bedenke, daß die Fäulniß im Politischen und Moralischen so gut wie im Physischen immer weiter um sich greift, und nach und nach auch die gesunden Glieder anstekt und verderbt." Berlinische Monatsschrift 1787, 1, p. 9 .

38 Hufeland, 1809. "Er wird dort [im KH, FD] mit Menschen aller Gattung, grösstentheils unsittlichen, liederlichen, an Müssiggang gewöhnten, in Verbindung gebracht, und er wird, nach einem Aufenthalt von 2 bis 3 Monaten, gebessert am Leib, aber verschlechtert an der Seele, aus dem Hospitale zurückkehren” 
thropy. In the homes of the poor, humanity which is dying off in hospitals is nourished and intimately interwoven with the art. ${ }^{39}$

It was as early as in the middle of the $16^{\text {th }}$ century that a Janus-faced debate on the modern state and the role of the individual began. The argument was settled around the possibility and necessity, if not the imperative, for the state to raise taxes. ${ }^{40}$ Thus, the labouring individual paying her or his taxes could no longer be regarded as plain and simply selfish. Consequently, a wealthy state could be seen as a state ruling the largest possible number of subjects being able to earn their living and pay their taxes, which became the undoubted common-sense position in the political economy of the $18^{\text {th }}$ century. Political and economic theory as well as confessional theology began to explore a new balance between the common best and private profit already before Adam Smith. Furthermore, medicine could serve political science and economics by providing an account of the demographic behaviour and the conditions of an increasing population. Finally, medicine began to develop the concept of a wealthy state managing the conditions of theoretically everyone's health by means of medical police. Within that frameset, developed over some 300 years, the arguments that poverty causes diseases and that a sick person runs the risk of pauperising as she or he is unable to earn her or his living due to sickness made health care a central mean of poor relief. Nevertheless, the debate on hospital versus domiciliary care in the early $19^{\text {th }}$ century shows that neither medicine nor public opinion or governmental authorities preferred centralised hospital care for the sick poor.

With respect to the discussion on choices between the informal and the formal which should be the focus here I would like to abandon the formula of the "hospital as the most complex institution of man", as individuals always choose to rely on complex institutions. The more closely regarded, the more complex they get, regardless of whether morality or religion, family/kinship or neighbourhood constitute the analysed institution. Social institutions always aim at simplifying complexity in order to attain the bare possibility to make a decision.

Going back to a lower level, the hospital as well as domiciliary care could be analysed as an organisation which in general could be understood as negotiated order. ${ }^{41}$ That way there may be a chance to open up a perspective which could be helpful in analysing the influence of changing institutions on more concrete organisations. Thus, we would lose a strict and clear line of demarcation between the

39 „Im Hospital sehen sie, wie es seyn sollte, hier, wie es ist, dort werden sie blos zu Künstlern gebildet, hier auch zu fühlenden, und dadurch erst ihre Kunst heiligenden Menschen, und der Sinn der Menschenliebe und Humanität, der dort so leicht erstirbt, wird genährt, und innigst mit der Kunst verwebt."

40 Schulze, 1986; Dross, 2004, p. 64-67; Schneider-Ludorff, 2004.

41 Watson, 2001. 
formal and the informal. Strengthening the aspect of agency and choice systematically seems to weaken the differences between formally or informally organised collective models of curing as well as an unquestionable barrier between magicl religious/medical attitudes and practices in healing. Like the pro-hospital position could declare with Hecker that "collecting for a hospital in favour of the suffering mankind is for surely no worse divine service than building a church", the contraposition stated the following Hufeland: "The whole affair has to be dealt with as a divine service and should be practised gratuitously and driven by inner incentive." ${ }^{42}$

In fact, we are facing blurred borders as mentioned by Susanne Hoffmann in her contribution to this volume. Maybe self-help could be analysed more precisely if understood as the active choice to rely on different organisational models providing (medical) help. But at the same time by blurring the borders we could gain a wider perspective of choosing: The historical choices made in a discourse inventing a new organisational model of curing as well as the choices of the patients whether to confide in hospital care or not and, not least, the choice of historians to stress the formal conditions of the informal - or vice versa.

Fritz Dross is assistant professor at the Institute for History of Medicine and Medical Ethics, Friedrich-Alexander-Universität Erlangen-Nürnberg, Germany.

42 Hecker, 1793, 62 (literally cited by Servaes, Hauptstaatsarchiv Düsseldorf, Großherzogtum Berg 5513, Bl. 82. Hufeland, 1809, 7. 


\section{References}

Gaulis d'Apples, Parallele entre les misericordes et les hopitaux. Lausanne, 1786. German translation [by Johann Christian Friedrich Scherf] "Parallele zwischen den Krankenbesuchanstalten und den Krankenhäusern," in Beyträge zum Archiv der medizinischen Polizei und der Volksarzneikunde 3, erste Slg. (1791) 132-148.

Johann Peter Brinckmann, Patriotische Vorschläge zur Verbesserung der Medicinalanstalten, hauptsächlich der Wundarznei und Hebammenkunst auf dem platten Lande, (First edition Düsseldorf, 1778) Reprint Düsseldorf, 1997.

Brinkschulte, Eva, "Die Institutionalisierung des modernen Krankenhauses im Rahmen aufgeklärter Sozialpolitik - Die Beispiele Würzburg und Bamberg," pp. 187-207 in Labisch / Spree 1996.

Isabelle von Bueltzingsloewen, Machines à instruire, machines à guérir. Les hôpitaux universitaires et la médicalisation de la société allemande (1730-1850). Lyon, 1997.

Chmielewski, Alexandra, "Reformprojekt ohne Zukunft: Die Heilanstalt und psychiatrische Klinik in Heidelberg (1826-1835)," pp. 49-66 in Engstrom / Roelcke 2003.

Chmielewski, Alexandra, "Norm und Autonomie. Legitimierungsstrategien süddeutscher Anstaltspsychiater zu Beginn des 19. Jahrhunderts," in Fangerau / Nolte 2006.

Cunningham, Andrew, Ole Peter Grell and Robert Jütte, eds., Health Care and Poor Relief in $18^{\text {th }}$ and $19^{\text {th }}$ Century Northern Europe, Aldershot, 2002.

Dinges, Martin, "Medicinische Policey zwischen Heilkundigen und «Patienten» (1750-1830)," pp. 263-295 in Karl Härter, ed., Policey und frühneuzeitliche Gesellschaft, Frankfurt/Main, 2000.

Fritz Dross, Krankenhaus und lokale Politik 1770-1850. Das Beispiel Düsseldorf, Essen, 2004.

Dross, Fritz, "»die Gemüse könnten füglich irgendwo anders gereinigt werden" Beobachtungen zur Geschichte der Anstalt als Irren- und als Krankenhaus," in Fangerau / Nolte 2006.

Eder, Klaus, "Institution," pp. 159-168 in Christoph Wulf, ed., Vom Menschen. Handbuch Historische Anthropologie, Weinheim, Basel, 1997.

Eric J. Engstrom and Volker Roelcke, eds., Psychiatrie im 19. Jahrhundert. Forschungen zur Gescchichte von psychiatrischen Institutionen, Debatten und Praktiken im deutschen Sprachraum, Mainz, 2003.

Heiner Fangerau and Karen Nolte, eds., "Moderne» Anstaltspsychiatrie im 19. und 20. Jahrhundert - Legitimation und Kritik, Stuttgart, 2006 (in print). 
Eder, Klaus, "Institution," pp. 159-168 in Christoph Wulf, ed., Vom Menschen. Handbuch Historische Anthropologie, Weinheim, Basel, 1997.

Nathaniel W Faxon, ed., The Hospital in Contemporary Life, Cambridge, 1949.

Hecker, August Friedrich, "Welches sind die bequemsten und wohlfeilsten Mittel, kranken Armen in den Städten die nöthige Hülfe zu verschaffen?," in Beyträge zum Archiv der medicinischen Polizey und der Volksarzneikunde 5 (1793), 3172. (Reprint in Johann Georg Krünitz, Oekonomische-technologische Encyklopädie oder allgemeines System der Stats-, Stadt-, Haus- und LandWirthschaft, und der Kunst-Geschichte, in alphabetischer Ordnung, vol. 47, Berlin, 1789, pp. 607-632).

Hensler, Philipp Gabriel: “Ueber Krankenanstalten,” pp. 273-284 in (A. L. Schlözers) Stats-Anzeigen 7. Bd., Heft 25-28 (1785). (Reprint in Archiv der medizinischen Polizei und der gemeinnützigen Arzneikunde Bd. 4, 2. Abt. (1786), 47-82).

Christoph Ludwig Hoffmann, Von der Nothwendigkeit, einem jeden Kranken in einem Hospitale sein eigenes Zimmer und Bett zu geben. Mainz, 1788.

Christoph Ludwig Hoffmann, Bestättigung der Nothwendigkeit, einem jeden Kranken in einem Hospitale sein eigenes Zimmer zu geben. Gegen Herrn Karl Strack. Mainz, 1788.

Calixte Hudemann-Simon, L'état et la santé. La politique de santé publique ou "police médicale» dans les quatre départements rhénans, 1794-1814, Sigmaringen, 1995.

Calixte Hudemann-Simon, L'état et les pauvres. L'assistance et la lutte contre la mendicité dans les quatre départements rhénans, 1794-1814, Sigmaringen, 1997.

Hufeland, C[hristoph] W[ilhelm], "Die Armenkrankenverpflegung zu Berlin, nebst dem Entwurfe einer Armenpharmakopöe," in Journal der practischen Heilkunde 29 (1809) [6. Stück], 1-25.

Jetter, Dieter, "Gemeinschaft und Absonderung der Kranken als antagonistische Faktoren historischer Hospitäler (1500-1900)," in Medizinhistorisches Journal 4 (1969), 121-138.

Dieter Jetter, Grundzüge der Krankenhausgeschichte (1800-1900), Darmstadt, 1977. Jütte, Robert, "Vom Hospital zum Krankenhaus: 16. bis 19. Jahrhundert," pp. 3150 in in Labisch / Spree 1996.

Jütte, Robert, "Health Care Provision and Poor Relief in Early Modern Hanseatic Towns," pp. 108-128 in Ole Peter Grell and Andrew Cunningham, eds., Health Care and Poor Relief in Protestant Europe 1500-1700, London, 1997.

Bernhard Jungnitz, Die konfessionellen Krankenhäuser der Stadt Münster im achtzehnten und 19. Jahrhundert, Herzogenrath, 1981.

Axel Karenberg, Lernen am Bett der Kranken. Die frühen Universitätskliniken in Deutschland (1760-1840), Hürtgenwald, 1997.

Ulrich Knefelkamp, Das Heilig-Geist-Spital in Nürnberg vom 14. - 17. Jahrhundert: Geschichte, Struktur, Alltag, Nürnberg, 1989.

Alfons Labisch und Reinhard Spree, eds., "Einem jeden Kranken in einem Hospitale 
sein eigenes Bett». Zur Sozialgeschichte des Allgemeinen Krankenhauses in Deutschland im 19. Jahrhundert, Frankfurt, New York, 1996.

Labisch, Alfons, "Stadt und Krankenhaus. Das Allgemeine Krankenhaus in der kommunalen Sozial- und Gesundheitspolitik des 19. Jahrhunderts," pp. 253296 in Labisch / Spree 1996.

Labisch, Alfons, "Einführung," pp. 7-67 in Brinckmann, 1997.

Alfons Labisch, und Reinhard Spree, eds., Krankenhaus-Report 19. Jahrhundert, Frankfurt/M., New York, 2001.

Lederer, David, "Die Geburt eines Irrenhauses: Die königlich-bayerische Irrenanstalt zu Giesing/München," pp. 67-93 in Engstrom / Roelcke 2003.

Lindemann, Mary, "Urban Charity and the Relief of the Sick Poor in Northern Germany 1750-1850," pp. 136-154 in Cunningham / Grell / Jütte, 2002.

Gerhard Emmanuel Lenski and Patrick Nolan, Human Societies. An Introduction to Macrosociology, (First edition New York 1970) $6^{\text {th }}$ edition New York et.al., 1991.

Micheline Louis-Courvoisier, Soigner et consoler. La vie quotidienne dans un hôpital à la fin de l'Ancien Régime (Genève 1750-1820), Genève, 2000.

John J Macionis and Ken Plummer, Sociology. A Global Introduction, Harlow et.al., 1997.

Adalbert Friedrich Markus, Von den Vortheilen der Krankenhäuser für den Staat, Bamberg, Würzburg, 1790.

Axel Hinrich Murken, Vom Armenhospital zum Großklinikum. Die Geschichte des Krankenhauses vom 18. Jahrhundert bis zur Gegenwart, Köln, 1988.

Nootnagel, Daniel, "Ueber Krankenbesuch-Anstalten," (A. L. Schlözers) StatsAnzeigen 7. Bd., Heft 25-28 (1785), 284-296. (Reprint in Archiv der medizinischen Polizei und der gemeinnützigen Arzneikunde Bd. 4, 2. Abt. (1786), 47-82).

Paul, Norbert, "Arztinitiativen bei der Gestaltung des Krankenhauses in der Zeit des Aufgeklärten Absolutismus," pp. 91-122 in Labisch / Spree 1996.

Ian Robertson, Sociology, (First edition 1977) $3^{\text {rd }}$ ed., New York, 1987.

Johann Jürgen Rohde, Soziologie des Krankenhauses. Zur Einführung in die Soziologie der Medizin, (First edition, 1962) $2^{\text {nd }}$ edition, Stuttgart, 1974.

Schneider-Ludorff, Gury, „Die Hospitalstiftung Landgraf Philipps des Großmütigen - Theologisches Programm und politische Legitimation," pp. 49-60 in: Arnd Friedrich, Fritz Heinrich, Christina Vanja, eds., Das Hospital am Beginn der Neuzeit. Soziale Reform in Hessen im Spiegel europäischer Kulturgeschichte, Petersberg, 2004.

Heinz Schott, ed., Der sympathetische Arzt. Texte zur Medizin im 18. Jahrhundert, München, 1998.

Schulze, Winfried, "Vom Gemeinnutz zum Eigennutz," in Historische Zeitschrift 243 (1986), 591-687.

Claudia Stein, Die Behandlung der Franzosenkrankheit in der frühen Neuzeit am 
Beispiel Augsburgs, Stuttgart, 2003.

Gunnar Stollberg und Ingo Tamm, Die Binnendifferenzierung in deutschen Krankenhäusern bis zum Ersten Weltkrieg, Stuttgart, 2001.

Karl Strack, Das allgemeine Krankenhaus in Mainz. Frankfurt/M., 1788.

Terhalle, Hermann, "Christoph Ludwig Hoffmann (1721-1807)," pp. 101-124 in Westfälische Lebensbilder, Bd. 14, Münster, 1987.

Vanja, Christine, "Keine Irren-Anstalt für Kurhessen. Psychiatriegeschichte im Spiegel einer ergebnislosen Diskussion zwischen 1806 und 1864," pp. 20-39 in: Peter Sandner, Gerhard Aumüller und Christina Vanja, eds., Heilbar und nützlich. Ziele und Wege der Psychiatrie in Marburg an der Lahn, Marburg, 2001.

Bettina Wahrig und Werner Sohn, eds., Zwischen Aufklärung, Policey und Verwaltung. Zur Genese des Medizinalwesens 1750-1850, Wiesbaden, 2003.

Watson, T. J., "Organizations: Negotiated Orders," pp. 10965-10968 in: Neil J. Smelser and Paul B. Baltes, eds., International Encyclopedia of the Social and Behavioral Sciences, vol. 10, Amsterdam et al., 2001. 